\title{
The Study of Accounting Measurement Mode Based on Fair Value Perspective
}

\author{
Wang SiYao \\ School of Management \\ Wuhan University of Technology \\ Wuhan,Hubei, China
}

\begin{abstract}
When it occurs financial crisis, most of the global financial assets may lose an active market, and the financial assets or liabilities fair value estimation will lose the foundation, a main body can not use fair value to measure its financial assets or financial liabilities. According to the experience of many years research, this paper carried out the appropriate improvements to the current fair value accounting to adapt to the new economic situation needs. The research results will play a very good help to ensure the stability of the fair value when the the financial crisis occurs.
\end{abstract}

Keywords-) measured at fair value; fair value accounting; accounting measurement mode

\section{INTRODUCTION AND LITERATURE REVIEW}

Financial accounting is an economic information system which is constituted by confirmed measurement and disclosure procedures.In this system, confirmation is inseparable from measurement, and disclosure also needs to measure.FASB said: "Confirmation" includes words and numbers while describing a project, the amount included in the report totals, and put measurability as a basic standard confirmation. Therefore, the measurement is a very important issue in financial accounting. As early as 1979, Japanese-American accounting scientist (Yuri Iriji) on that: "accounting measurement is the core issue of the accounting system." (Yuri Iriji, 1979: 29). About the meaning of accounting measurement, Western financial accounting literature have different versions.

1966, AAA "Basic Accounting Theory" (A-SOBAT) believes that the accounting major is a economic information that delivers program of subject the recognition, measurement. In the evaluation of accounting information, it establishes four basic criteria include measurability, in explaining measurability he pointed out that money is essential but not the only digital measurement accounting personnel employed. 1970, APB No.4 believes that the financial accounting function is to provide quantitative information with primarily financial nature in order to help the accounting staff to make economic decisions.Financial accounting is a branch of accounting, which includes a statement of financial condition and operating results. (APB statement No.4,1970, par.9) 1984, FASB noted that "the assets, liabilities or equity. variation must have the relevant measurement attribute, and can be fully and reliably using money as a unit of measurement." Overall, the measurement of financial accounting mainly refers to confirm accounting information in the financial statements, it needs to be with a text description and the amount of money, ie the currency of measurement. The information disclosed in the table outside can be qualitative information or qualitative and quantitative information, the latter includes both quantified in monetary terms and in other units of measurement measurement, that is the amount by which the performance of other units of measurement. Expressed as weight in kilograms, according to the meter indicates the length, with time, date represents a time span, and so on.

\section{MEASUREMENT MODEL}

Measurement mode is determined by the measurement units and measurement attributes, unless there is hyperinflation or deflation, countries generally use their own regional currency measurement units, such as the RMB, U.S. dollars, Hong Kong dollars and so on. Measurement basis or measurement attributes can be simply understood as the different time measurement of different methods can be used. Measured in monetary terms, the basic measurement methods is the market price (or exchange price). That is, the market price or the exchange price (because the market price is for the exchange) is the basis of the method of accounting measurement. If to distinguish time orientation, which is divided into the past, and now and future in three different time periods, then there will be nine basis or attributes can be measured in money. (As shown in Table 1).

Table 1 Time Frame

\begin{tabular}{|l|l|l|l|}
\hline foundation & \multicolumn{1}{|c|}{ past } & \multicolumn{1}{|c|}{ now } & Future \\
\hline entry rice & $\begin{array}{l}\text { (1) past entry } \\
\text { price }\end{array}$ & $\begin{array}{l}\text { (4) current } \\
\text { entry price }\end{array}$ & $\begin{array}{l}\text { (8) future } \\
\text { entry price }\end{array}$ \\
\hline $\begin{array}{l}\text { Exit or } \\
\text { selling price }\end{array}$ & $\begin{array}{l}\text { (2) past exit } \\
\text { price }\end{array}$ & $\begin{array}{l}\text { (5) current } \\
\text { exit price }\end{array}$ & $\begin{array}{l}\text { (9) future } \\
\text { exit price }\end{array}$ \\
\hline 3 others & $\begin{array}{l}\text { (3)modified } \\
\text { past amount }\end{array}$ & $\begin{array}{l}\text { (6) value in } \\
\text { use }\end{array}$ & $\begin{array}{l}\text { (7) current } \\
\text { equalitarian } \\
\text { price }\end{array}$ \\
\hline $\begin{array}{l}\text { 4alternative } \\
\text { s }\end{array}$ & &
\end{tabular}

The nine kinds of measurement attributes in Table 1 is provided to IASB and FASB to consider by IASB and FASB joint conceptual framework staff. They are: (1) the last recorded price; (2) the last sale price; (3) The past correction amount; (4) The current recorded prices; (5) the current selling price; (6) the value in use ; (7) the current average price; (8) accounted for future price; (9) future sales price. 
Nine measurement attribute does not seem to mention the historical cost and fair value to be discussed in this article, in fact, historical cost is the purchase price or the last sale price; fair value is the current sell price (according to FASB understanding) or also include the current purchase price.

\section{FAIR VALUE MEASUREMENT AND FAIR VALUE ACCOUNTING}

Fair value accounting can also be called Mark-to-market accounting. FAS157 thinks fair value means: in the measurement day, it is the the price market participants received or payed when transferred liabilities. This definition (ie FASB Financial Accounting Standards No. 157, "fair value measurement", hereinafter referred to as the FAS157) has become a hot academic controversy. To understand this definition, it must be contrasted with the same historical cost. We note that, in this definition statements, not to mention the "trade date" but to use the reference of "measurement date", apparently we can conclude that the measurement date (refers to the initial measurement date) is not equal to the transaction date.In definition, not to mention the price agreed between the two bodies,but it is expressed as the price of that market participation by the sale of assets received or transferred liabilities to pay. Obviously, the value of the measurement is not realistic transaction, nor is the actual price that have occurred, it is an orderly transfer market reference price of market participants to estimate the hypothetical trading assets and liabilities of the selling price.

As can be seen, this definition is completely in line with the main characteristics of derivatives, first, it changes with the changes of basis variables, and there is no or only minimal prior initial investment, second, ti was settled in the next time (the transaction is completed). Derivatives instruments trade not wait until the next time settlement, but determining the buying and selling of derivatives contracts of the above conditions. At this time, in addition to a small margin, the amount can only be measured at the fair value of derivative instruments.

Overall, therefore, the basis of the fair value is the market price (the exchange price). Specifically, it is based on imaginary sell price transactions (sale of an asset is the expected cash inflows or transfer a liability when the expected cash outflow) in the measurement of that day. The market price (or exchange price) is the price of an orderly transaction, and it is carried out in a completely voluntary exchange on the basis of mutual lust, and the price has been demonstrated for some time in the market. In the past and present, the transaction is a large amount, in line with business rules, the offer is open, fair and can be made at any time. Determination the fair value is not based on the exchange of the two main parties, but it is base on the pricing market participation made by making assets and liabilities in an active market. The reason it is not called "debt settlement price" and but called "transfer pricing" is that the debt was not settled and continued to be hold by the market participation in other markets.

According to the characteristics of fair value, the fair value measurement also has the following features. First, its the measurement date (initial measurement date) is not a trading day, because it is based on hypothetical transactions for the object, not regarded as an object of reality transaction that have occurred, the initial measurement date is the intended transaction "Confirmation Pledge Day". Second, the amount of measurement is not reached between the two bodies in the trading day. but to estimate the fair reimbursement based on an active market.

Third, as an estimated price, fair value is estimation have three level: One level estimation, the same assets and liabilities public, equitably quoted in an active primary market as a fair value; Two level estimation is an open and fair offer with similar assets and liabilities in active markets, it is based subject to the necessary adjustments; Three level estimation, that lack of observable market prices, using the estimated main input variables (through a variety of estimation techniques, such as option pricing model, the discounted value of future cash flows) to estimate. Enterprises should maximize the use of observable market input variables, especially the one level estimation. One level estimation is the best estimation of fair value, and enterprises should minimally adopt enterprise unobservable input variables, that three level estimation. Fourth, the project which uses fair value measurement, in addition to the initial measurement, in the duration of the transaction before the end of holders, after each reporting period, it will re-estimate and adjusted to market value as possible.

Fair value accounting refers to certain items (mainly refers to financial assets and financial liabilities, mainly the former) measured at fair value, and recognized in the financial accounting in two steps: First official recording (by double-entry bookkeeping requirements), and then included in the financial statements, becoming the accounting model of the table within the project financial statements, such as asset holders continued to hold, should be that it is available for sale in the transaction, thus it should be subsequently measured (ie revaluation) according to the reporting date market price or market value of similar assets, and confirm the change in fair value (ie the difference between the book value and the current fair value, which is equivalent to realize gains and losses but not implemented). According to American accounting standards (FAS115), if the assets is in trading, fair value, changes in fair value should be recognized in profit or loss, if the assets belong to the available-for-sale, changes in fair value should be recognized in other comprehensive income portion of gains or losses.

Features of fair value accounting are: an enterprise's current income includes both realized gains or losses, also includes the expected unrealized gains or losses. Meanwhile, the net assets in the balance sheet will also include the expected impairment asset value or unrealized. In this accounting model, some people think that a company's assets and liabilities reflect the current market price information, so that transparency and truthfully. Some people think that this is a distortion of the true economics business, and it is to use estimation to replace the accounting. In the case of an economic crisis or financial crisis, disagreement is even greater for fair value accounting evaluation. 


\section{CONCLUSION}

Through the above analysis, we made a number of recommendations for improvements to the fair value measurement. Given the fundamental issue of fair value accounting is the financial assets, measured at fair value to recognize in the financial statements, in subsequent confirmation, it must be transferred to the market, and the changes in the fair value of the produce should also be acknowledged. This makes the body net income are reported in the financial statements, including gains realized and unrealized, distorting the truth of corporate management, investment, financial results, a departure from the essential characteristics of financial accounting and financial statements, which must truthfully reflect a body economic reality. At the same time, taking into account the fair value measurement attribute is still useful for financial instruments, it is the most relevant measurement attribute, for derivative financial instruments, it is the only relevant measurement attribute. The essential characteristics of financial accounting and financial statements should not be artificially changed, and financial accounting should never become a financial estimation.

\section{References}

[1] Chang Yan. Thinking of fair value accounting measurement model [J]. Contemporary economic, 2010,04: 134-135.

[2] Hao Zhenping, Zhao Xiaolu. Three levels of basic theoretical issues related to fair value accounting [J]. Accounting Research, 2010,10: $12-18+95$.

[3] Dong Birong. Thinking about the nature of the fair value of [J]. Accounting Research, 2010,10: 19-25 + 95.

[4] Huang Shizhong. Fair Value Accounting: measurement model for the 21st century [J]. Accounting Research, 1997,12: 2-5.

[5] Zhao Jing. Application of fair value accounting measurement attributes explore prospects [J]. Theorists, 2006, S1: 36-37.

[6] Qi Ruixiang. Thinking of fair value accounting measurement model [J]. Shanxi Finance and Tax College, 2006,06: 57-58. 